\title{
AN INTERACTIVE CONSTRUCTION PROJECT FOR METHOD OF STATEMENT BASED ON BIM TECHNOLOGIES FOR HIGH-SPEED MODULAR BUILDING
}

\author{
Sergei Sychev ${ }^{1}$, Gennady Badin² \\ 1,2Saint Petersburg State University of Architecture and Civil Engineering, \\ Vtoraja Krasnoarmejskaja ul. 4, St. Petersburg, 190005, Russia \\ 'sasychev@ya.ru, ${ }^{2}$ gennady.badin@mail.ru
}

\begin{abstract}
The concept and methodology for interactive design of Methods of Statement based on the use of technical and informational models, technological charts, and 3D models of construction facilities is suggested. The article presents the peculiarities and principles for the speed-up assembling (erection, disassembling) of unified modular structures, pre-fabricated block sections, their transportation and rapidly erected modular buildings. The high speed of construction is reached due to the qualitative interactive Method of Statement, logistics of sequence and completeness of information, use of BIM technologies, unconditional use of permanent quality control of works execution at all construction stages with the automatic control of accuracy as to positioning of construction structures and execution of construction and technological operations.
\end{abstract}

\section{Keywords}

Fast assembly, pre-fabricated unified modular structures, rapidly erected modular buildings, the high speed of construction, method of Statement, logistics, BIM technologies, quality control, accuracy control

\section{Introduction}

In the modern context of construction operations, there is the burning need for elaboration of a comprehensive assessment methodology and analysis for engineering solutions efficiency, selection of a rational technology for bulk modulus erection in definite construction conditions. It is impossible to speed up the scientific and technical progress in the field of high-speed construction of modular buildings without large-scale implementation of principally new technologies ensuring high labor capacity, efficiency and quality of modular buildings erection. The search for the optimal technology for modular buildings construction is connected with the definition of cumulative parameters and characteristics of the system providing the minimization of stated costs, labor input and work duration, social and economical, ergonomical and other requirements (Adam, 2001; Asaul, et al., 2004; Afanasiev, et al. 2000; Afanasiev and Afanasiev, 1998; Bolotin, et al., 2011; Verstov and Badyin, 2010; Kazakov and Sychev, 2015).

In recent years in the construction practice, we rarely meet a detailed Method of Statement. It is explained for the following reasons: unavailability or respective companies and specialists, qualified designers, construction engineers able to quickly and qualitatively perform the project order; outdated regulatory reference base considering for the project safety, environmental compatibility, efficiency, constructability; non-availability oforders and necessity for the mandatory availability of this document, Method of Statement, for the project construction and handover to the State Commission. Instead of the detailed plan for the Method of Statement, the quarterly schedule for extent of financing is presented. The dynamic technology for the construction and works execution is replaced with the static master plan combined with the site plan of all the engineering and technical communications. The prevalence of the work organization over the technology often leads to negative issues related to the works safety, accidents, injuries, workers death, buildings structures collapse (Matveyev, 2000; Ugorelova, 2000; Anderson and Anderson, 2007; Day, 2011; Fudge and Brown, 2011; Knaack, et al., 2012).

The Method of Statement is an organizational and process document elaborated for project implementation and working documents preparation 
and defining the construction works processes (technological processes and operations), quality of their performance, time, resources, and safety events (Central Scientific Research Institute of the Organization for Building Mechanization and Technical Aid, 2007a).

A process flow chart is the organizational and process document elaborated for the performance of processes and defining the composition of operations and mechanization means, quality requirements, labor input, resources and safety events (Central Scientific Research Institute of the Organization for Building Mechanization and Technical Aid, 2007b).

Summing up the above, we may say that there are contradictions in the design documents for the Method of statement mandatory for completion at construction of any facility.

\section{Subject, tasks and methods}

The main aim of the researches from Saint Petersburg State University of Architecture and Civil Engineering is the developing the first Russian interactive Method of Statement based on BIM (Building Information Modelling) technologies suggest the concept which according to the technology designers assessment will allow for anytime obtaining of multidimensional visualization of erection of building structures, complex joints, accuracy of technological equipment structures and units positioning due to the sensors installed in erection elements. Designers and builders in the course of construction and erection works execution will be able to see the way and sequence, use of technical tools (cranes, hoists, winches, etc.) to be applied for erection (assembling, disassembling) of structures or another task. Implementation of interactive technological erection processes will allow for fundamental changing and supplementing the applicable system for construction and technological project preparation. Thereby the reliability, strength, stability, safety of a certain working process may be multiply checked. The result is that we will reduce construction duration, labor capacity, reach the right price and quality ratio for the project, save on new pre-fabricated parts production. Project errors risks decrease significantly, the working documents quality enhances and by extension, the construction works execution quality. The interactive work differs from the common virtual reality as follows: a designer sees the surrounding environment with consideration of additional factors and conditions in which a designed project will be erected. In course of design the information is introduced through the special glasses which may have set visual commands ensuring a step-by-step guidance of technological calculations, options for equipment positioning or right actions of an engineer (Badyin and Sychev, 2015; Kazakov, et al., 2015; Sychev, 2015a; Sychev, 2015b).
The main purpose for creation of the interactive Method of Statement is to realize the tools allowing on the basis of objective (i. e. received with use of measurement devices with a definite accuracy class depending on the control requirements and undergone the state certification through checking laboratories) and actual data for creation of the models of constructed (restorated) facilities and make analysis and conformity assessment of the current status (condition) of real facilities at all construction and restoration stages to the accepted design and construction solutions with successive evaluation of scope and cost of the executed works (Figure 1). Besides the system of the interactive Method of Statement is to be able to introduce necessary changes into facilities construction (restoration) schedules on the basis of obtained data which characterize the conformity of the current status of facilities construction (restoration) to the requirements of planning and controlling authorities. On the interactive Method of Statement basis, it is possible to build up the system for support and decision taking for the construction industry (its sections) control and management authorities. The most important function of the interactive Method of Statement is the search of most rational options for control and management with due consideration of various factors impact.

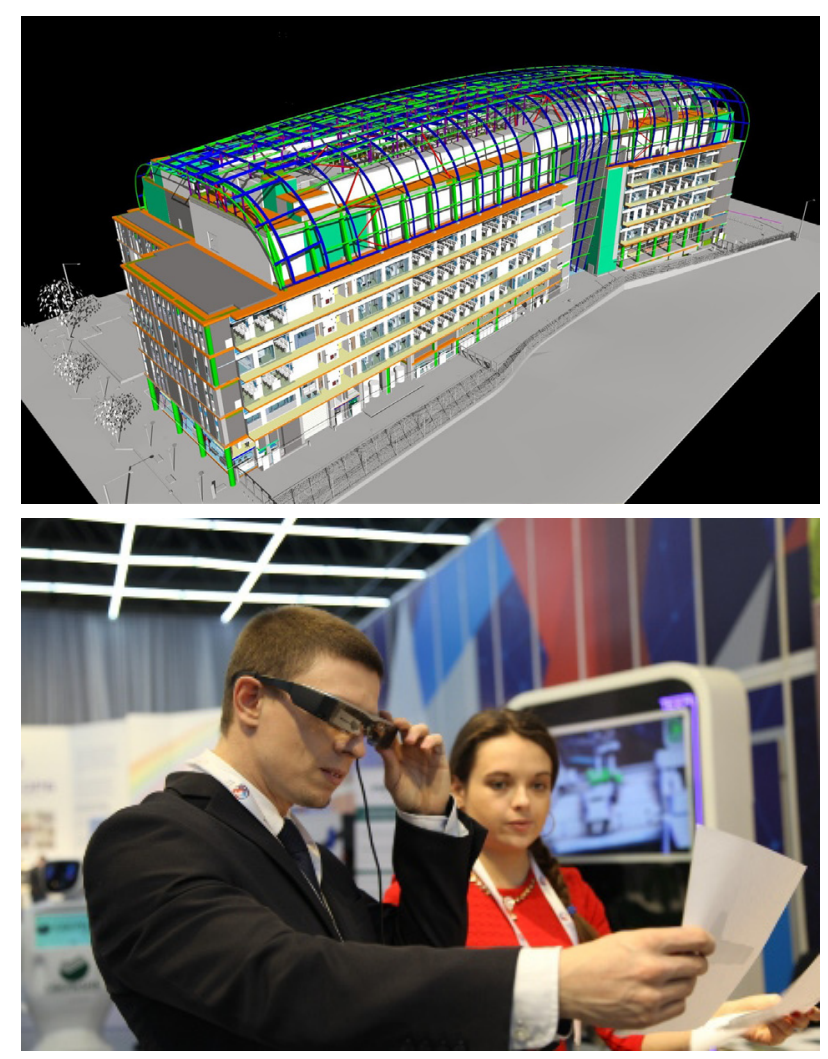

Figure 1. Interactive model of the Method of Statement for high-speed buildings erection with modular attics (on the left) and construction virtual reality means (on the right) based on BIM technologies 
The main method, which is used in the authors' research is the combination of BIM and real-world example of the construction progress, which is integrated closely enough with structures stocks, machines fleet, regulatory requirements, technical regulations considering construction quality control, safety, reliability, efficiency (Figure 2).

\section{Results}

On the face the glasses do not differ from common ones however they show the additional information about many characteristics and technical and economical values of processes: movement speed of cranes, machines, mechanisms, transport; safe operational distance; productive and labor capacities; In the perception of the authors the technology of interactive Method of Statement will allow for receiving of $3 \mathrm{D}$ visualization of such processes as structures erection, assembling of complex joints and units of technological equipment considering works execution safety and erection accuracy with use the installed piezometric senses, GPS or GLONASS senses. Materially all norms of set of rules (SP), SNiP, ENiR, VNIR, TER, MRT, etc. are included in the PC memory with glasses intake unit. There is no need for a paper drawing in many copies.

In AutoCAD in the coordinate imaging system it is possible to design the electronic version of all plants, erection elements tying-in to a building grid for spatial orientation of erection of structures with senses, elements cut and paste and object editing; to inspect various variants and versions many times prior to print out. Several floating viewports for complex object may be created. Following the comparative analysis and comparison, the optimal variant is to be selected as the final solution of a certain engineering task.

BIM Method of Statement presents the possibility of operative obtaining of required information often without any additional queries to a designer and line management. The advantages of the technology for the interactive Method of Statement BIM are evident for the model allows for monitoring the project from inside with all its interrelations and details of space and planning and engineering and technological solutions, applied materials and equipment.

Construction companies in the course of the developer's project implementation face the necessity for the control of completeness and quality of construction and erection works execution. It is possible to timely obtain actual information about construction progress, constantly control execution of technical plans for construction from various sources: reports, communication means, construction sites. However, there is a more efficient, simple and fast way of obtaining the information for taking decisions - the construction progress control system. It allows obtaining evaluation summaries for all the constructed facilities in real time and if required perform the operative analysis of critical situations by a foreman, a site supervisor, chief engineer.

Thus, the interactive system for control of the works execution, as the main research result, is the uniform closed electronic space created by integration of information technologies used by all the specialists participating in implementation of a facility - from survey and design to construction. The implementation of such system for the works execution is to be considered as an innovation approach aimed at getting new competitive advantages by a construction company and receiving true economic feedback from the funds invested into the project. The informational system of the interactive Method of Statement being correctly adjusted is aimed at constant monitoring of ongoing processes in a monitored facility as regards the set program of its development, helps to reveal causes of arising deviations, non-use of reserves and possibilities of enhancing of construction efficiency, helps to elaborate variants of optimal solutions for elimination of an occurred unfavorable situation in the form of inaccurate erection of structures, violation of requirements of the Method of Statement, concealment of defect (Figure 2).

Accordingly, the objective control service of construction stages by means of the interactive Method of Statement lies in the formation of the generations of spatial data on a constructed facility and is as follows (Figure 3 ):

- Service of gathering information on the basis of satellite data, aerial photography and surface laser scanning as the complex of events aimed at the formation of the generations of spatial data, submission of spatial data for control function implementation including the stage of design and survey works.

- Service of data processing including the innovative technologies for digital processing of

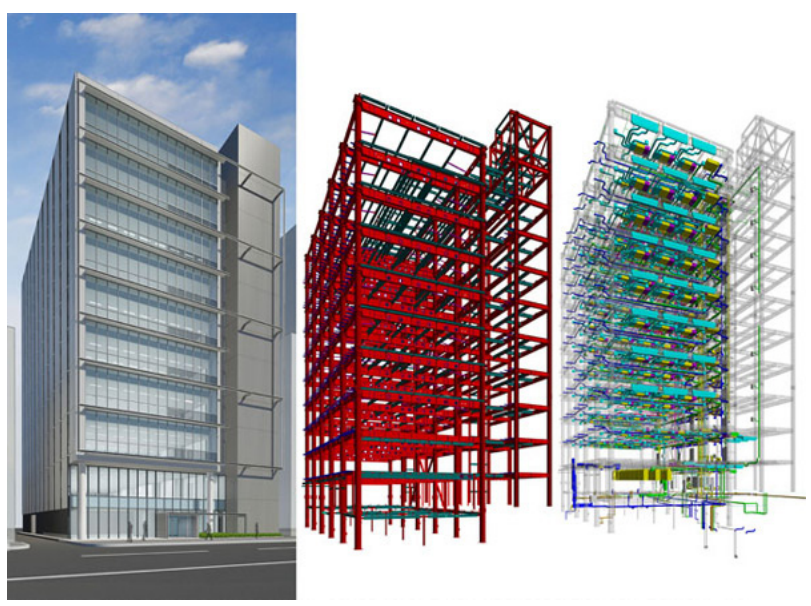

Figure 2. The example of building 3D model of a rapidly erected modular building as the basis for creation of the 5D interactive Method of Statement based on BIM technologies 

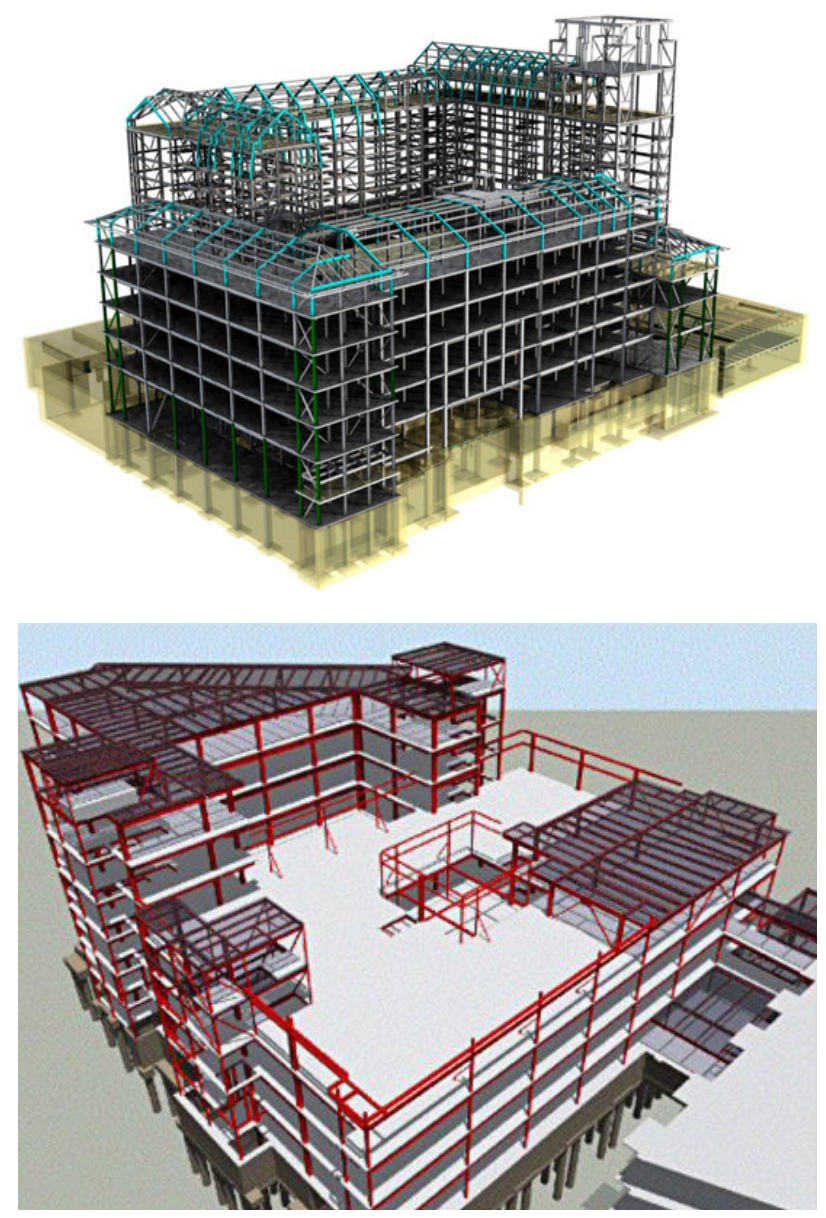

Figure 3. An example of building 3D model of a rapidly erected modular building with attics as the basis for creation of the 5D interactive Method of Statement based on BIM technologies

spatial data, assessment of construction stages and infrastructure status as well as performance of international norms and requirements of GOST, SP, SNiP.

- Service of analysis, evaluation and visualization of objective information representing the system of events for comparing of the data available on current construction progress of facilities to the design and engineering documents as consistent with construction stages, GOST requirements and regulatory and technical documents including design and engineering ones and keeping the data base up to date.

The interactive control procedure contains several stages. Control measurement is executed one time in a reporting period (e.g. upon closure of a working day). The measurement results are incorporated into respective reporting documents, estimates, etc. as per a regular procedure by an authorized person (controller, foreman, etc.). The survey of a construction facility is taken form fixed locations, viewing angles, etc. with tools by the same authorized person or fixed cameras. The reports are incorporated in databases for data upload into GIS according to BISDM model. The key procedure is the comparison of real construction parameters with design documents. The main sources for data comparison are as follows:

- Reporting documents for the reporting period (incorporated as data bases or respective clauses).

- Field survey results.

- Facility GIS-BISDM-model received from CAD.

- Actual building condition GIS-model (BISDM).

The geoinformation model based on ArcGIS is an architectural solution for the objective control system for construction projects. Modern construction objective control means operate with 4D-models of constructed facilities. 4D unites the facility 3D-model with the respective works of activity progress chart of construction works and includes the 4 parameters: three spatial coordinates and time. Such model allows for visual monitoring of all planning errors by modeling the construction process in time. It is worth noticing that the basis for any objective control system is the geoinformation system (GIS) which is the virtual representation of a construction site (or sites) where facilities are interrelated in geographic space. GIS allows users to get the access to an information model, construction works schedule and other information as to the selected facility and allows management of all levels to assess overall construction progress on all sites. It is possible to say that objective control means represent a special GIS realizing GIS potential and technological solutions for collection, processing and creation of required data on a construction facility.

For recent 30 years, the main methods for forming and management of the construction environment and in adjacent industries have turned out to be unstable. Currently the interested parties most often use in construction projects such technologies as building information model (BIM) among other traditional computer-aided design systems (CAD) in order to create and store the data on buildings. Besides, BISDM (the information model of a building internal space, data model used in GIS software and allowing for efficient geodata exchange and interaction with other platforms (Figure 4, 5). The task for heads of construction companies is query, analysis and submission of this information for all buildings within a district or even more geographic region. Thereby in many cases the construction data is contained in electronic tables and paper or electronic floor-plans without an actually organized data management system.

On account of import and aggregation in GIS of geometric and text data from several files BIM and/ or CAD, all the potential of BIM Method of Statement may be used and extended by way of its integration with related spatial data on the neighbourhood area, district, region (Figure 6). 


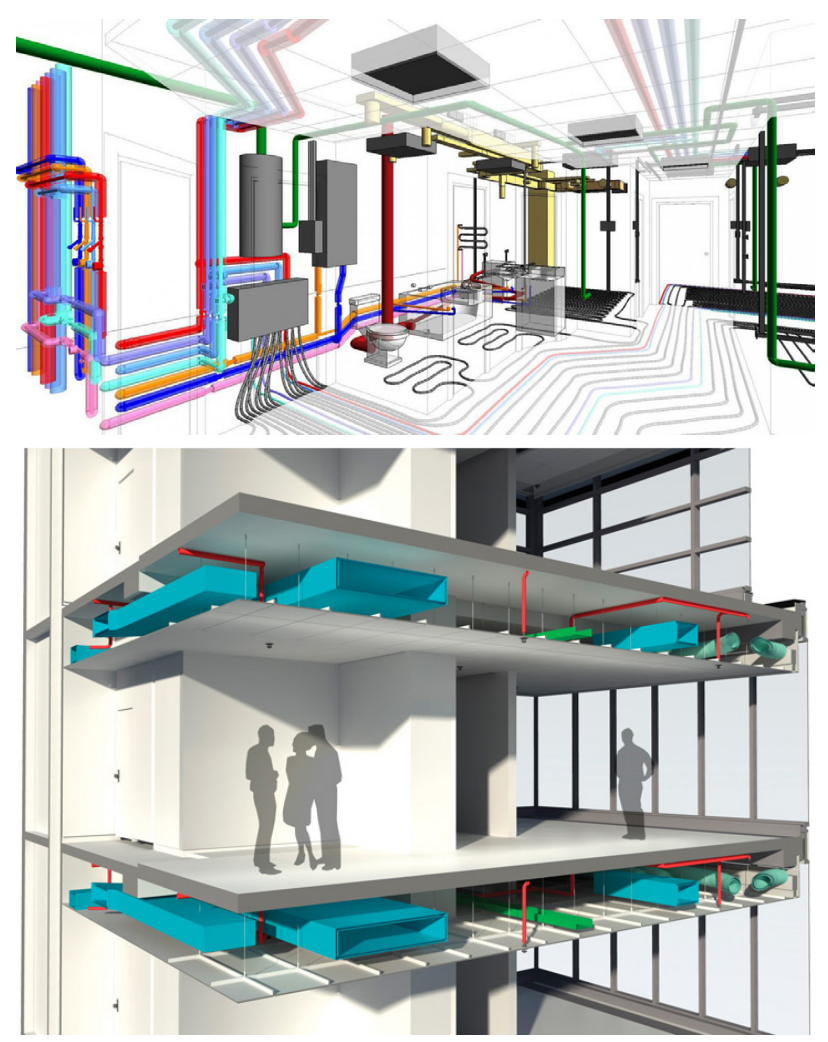

Figure 4. Building of the 4D of a rapidly erected modular building with specification of installed utilities as the basis for the creation of $5 D$ interactive Method of Statement based on BIM technologies.

A significant role in construction project management is played by Integrated Workplace Management System (IWMS). A comprehensive part of the entire construction project life cycle management may be done with use of the program IBM TRIRIGA. TRIRIGA functionality allows for solving of the whole set of tasks as regards construction, monitoring and maintenance. The program may be supplied modularly depending on the customer's requirements.

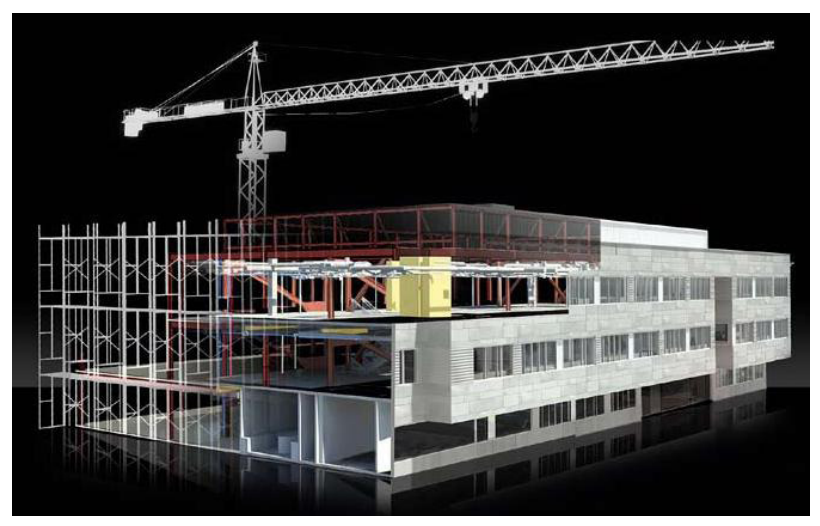

Figure 5. Building of the 4D model of the interactive Method of Statement for the modular building erection works as the basis for the creation of the 5D model based on BIM technologies

\section{Conclusions}

The main results are given in the general conclusions of the article. Currently the authors make elaborations in field of compatibility of calculated, regulatory and BIM models of a building. In future, it will be possible to introduce corrections to the BIM model based on the results of calculation in the mode of conversion of calculated program complexes files, which will help to avoid the noncompliance of a building calculated model and accepted structural and technological solutions and will make the expertise of a constructed facility and the construction and erection works execution more efficient.

The main conclusions are:

1. This work suggests a methodology (methods, algorithm, software) for high-end system rapidly erected modular buildings, the dependence of the assembly parameters on the technological characteristics of prefabricated modules, comprehensive mechanization facilities and automation of the erecting equipment was defined (operation time and work labour input decreased by $40 \%$, the accuracy of mounting joints increased by $50 \%$ ).

2. An interactive project of execution of work based on technical and information models, flow diagram and miniatures of construction projects in $5 \mathrm{D}$ system of unified modular constructions was developed. New interactive Method of Statement takes into account the dynamic changes of the construction. It is the operative document, based on the vast database of the experimental data on materials, machines, automatic mechanisms, processes and methods of construction.

3 . This work suggests the system of complexvirtual support for visual tracking and the choice of the work production optimum alternative and the construction planning design, which eliminates the need to print a large volume of paper documents. The visual design based on the interactive Method of Statement increases the quality of the work

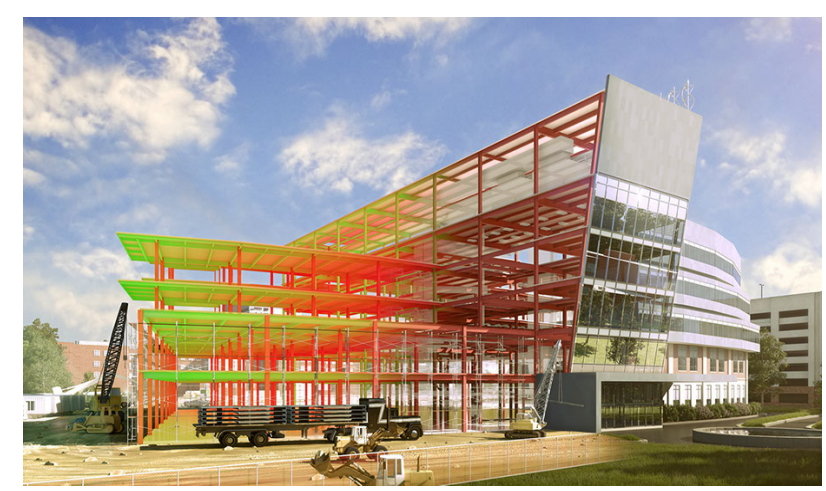

Figure 6. BIM data imported into GIS combined in the common $5 \mathrm{D}$ model (coordinates, time, movement) of construction and erection works execution with the possibility of movement across a facility and imbedded into «visual environment» 
production plan and the construction method statement by $50-55 \%$ : during the assembling saves up to $15 \%$ of the work and materials cost; saves up to $20 \%$ of the time during the assembling modulus; saves the expense of accuracy of calculations up to $10 \%$; saves up to $30 \%$ of payroll; saves up to $20 \%$ of the equipment and materials value; saves up to $30 \%$ on the time and cost of designing.

\section{References}

Adam, F.M. (2001). Sovershenstvovanie tehnologii stroitel'stva modul'nyh bystrovozvodimyh malojetazhnyh zdanij [Improvement in the technology for construction of modular, rapidly erected low-rise buildings]. PhD thesis in Engineering Science. Saint Petersburg, p.154 (in Russian).

Afanasiev, A.V., Afanasiev, V.A. (1998). Organizacija stroitel'stva bystrovozvodimyh zdanij i sooruzhenij. Bystrovozvodimye i mobil'nye zdanija i sooruzhenija: perspektivy ispol'zovanija $v$ sovremennyh uslovijah [Arrangement of construction of rapidly erected buildings and structures. Rapidly erected buildings and structures: prospects of use in the modern conditions]. Saint Petersburg: Stroyizdat, pp. 226-230 (in Russian).

Afanasiev, A.A. et al. (2000). Tehnologija vozvedenija polnosbornyh zdanij [Technology for pre-fabricated buildings' erection]. Moscow: Publishing House ASV, 287 p. (in Russian).

Anderson, M., Anderson, P. (2007). Prefab prototypes: Site-specific design for offsite construction. New York: Princeton Architectural Press, 123 p.

Asaul, A.N., Kazakov, Yu.N., Bykov, V.L., Knyaz, I.P., Erofeyev, P.Yu. (2004). Teorija i praktika ispol'zovanija bystrovozvodimyh zdanij [Theory and practice of use of rapidly erected buildings]. Saint Petersburg: Publishing House Humanistika, p.463 (in Russian).

Badyin, G M., Sychev, S.A. (2015). Analysis of rapidly erected structures' erection and operation defects [Analiz defektov montazha i jekspluatacii bystrovozvodimyh konstrukcij]. Penza: Publishing House "Akademija Estestvoznanija" [Academy Of Natural History], No. 2, pp. 218-223 (in Russian).

Bolotin, S.A., Dadar, A.Kh., Ptukhina, I.S. (2011). [Imitacija kalendarnogo planirovanija v programmah informacionnogo modelirovanija zdanij i regressionnaja detalizacija norm prodolzhitel'nostej stroitel'stva [Simulation of calendar planning in BIM programs and regressive detalization of construction duration rules]. Magazine of Civil Engineering, 7 (25), pp. 82-86 (in Russian).

Central Scientific Research Institute of the Organization for Building Mechanization and Technical Aid (TsNIIOMTP) (2007a). Metodicheskie rekomendacii po razrabotke $i$ oformleniju proekta organizacii stroitel'stva i proekta proizvodstva rabot [Methodological recommendation for the development and preparation of a construction project, order of works]. MDS 12-81.2007. Moscow (in Russian).

Central Scientific Research Institute of the Organization for Building Mechanization and Technical Aid (TsNIIOMTP) (2007b). Metodicheskie rekomendacii po razrabotke i oformleniju tehnologicheskoj karty [Methodological recommendation for the development and preparation of a technological chart]. MDS 12-29.2006. Moscow (in Russian).

Day, A. (2011). When modern buildings are built offsite. Building Engineer, 86 (6), pp.18-19.

Fudge, J., Brown, S. (2011). Prefabricated modular concrete construction. Building Engineer, 86 (6), pp. $20-21$.

Kazakov, Yu.N., Sychev, S.A. (2015). [Sistema vozvedenija domov zavodskogo izgotovlenija [System for erection of pre-fabricated houses]. In Proceedings of the International Scientific and Practical Conference: Science and education in modern society, Tambov, pp. 63-65 (in Russian).

Kazakov, Yu.N., Sychev, S.A., Nikolskiy, M.S. (2015). Innovacionnaja tehnologija bystrogo vozvedenija jekonomichnyh zhilyh domov iz optimizirovannyh sjendvich-panelej v Rossii [The innovative technology for rapid erection of cost-efficient residential buildings made of tailored sandwich panels in Russia]. International Journal of Applied and Fundamental Research, 9 (4), pp. 577-586.

Knaack, U., Chung-Klatte, Sh., Hasselbach, R. (2012). Prefabricated systems: Principles of construction. Switzerland: Birkhauser, $67 \mathrm{p}$.

Matveyev, Ye.P. (2000). Teorija, metody i tehnologii rekonstrukcii zhilyh zdanij razlichnyh periodov postrojki [Theory, methods and technologies for restoration of residential buildings]. PhD thesis in Engineering Science. Moscow, Moscow State University of Civil Engineering, p. 48 (in Russian).

Sychev, S.A. (2015a). Ocenka tehnologichnosti montazha zdanij i sooruzhenij iz modulej zavodskoj gotovnosti [Constructibility assessment for pre-fabriicated modular buildings and structures' erection]. Journal "Global Scientific Potential", 9 (54), pp. 37-41.

Sychev, S.A. (2015b). Ocenka kachestva tehnologii vysokoskorostnogo vozvedenija zdanij iz blok-modulej s uchetom kriterija bezopasnosti [Quality assessment with regard to the technology for high-speed erection of modular buildings with account of safety criteria]. Journal "Zhilishchnoe Stroitel'stvo", 8, pp. 3-8.

Ugorelova, N.V. (2000). Avtomatizacija montazha sbornyh stroitel'nyh konstrukcij [Prefabricated construction structures' erection automation]. PhD thesis in Engineering Science. Moscow, 167 p. (in Russian).

Verstov, V.V., Badjin, G.M. (2010). Osobennosti proektirovanija i stroitel'stva zdanij i sooruzhenij v Sankt-Peterburge [Peculiarities of designing and constructing buildings and structures in Saint-Petersburg]. Vestnik grazhdanskikh ingenerov [Bulletin of Civil Engineers], 1 (22), pp. 96-104 (in Russian). 